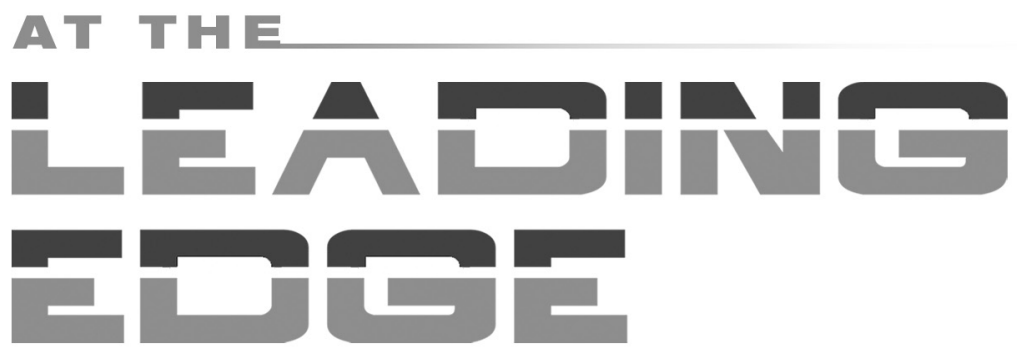

The ATLAS and CMS LHC Experiments

Editor

\title{
DAN GREEN
}

Fermi National Accelerator Laboratory, USA 


\section{Published by}

World Scientific Publishing Co. Pte. Ltd.

5 Toh Tuck Link, Singapore 596224

USA office: 27 Warren Street, Suite 401-402, Hackensack, NJ 07601

UK office: 57 Shelton Street, Covent Garden, London WC2H 9HE

\section{Library of Congress Cataloging-in-Publication Data}

At the leading edge : the ATLAS and CMS LHC experiments / edited by Dan Green.

p. $\mathrm{cm}$.

Includes bibliographical references.

ISBN 978-9814277617 (alk. paper) -- ISBN 978-9814304672 (pbk : alk. paper)

1. Large Hadron Collider (France and Switzerland) 2. Nuclear counters. 3. Symmetry (physics)

4. Particles (Nuclear physics) I. Green, Dan.

QC787.P73A8 2010

539.7'7--dc22

2009045137

\section{British Library Cataloguing-in-Publication Data}

A catalogue record for this book is available from the British Library.

Copyright $\odot 2010$ by World Scientific Publishing Co. Pte. Ltd.

All rights reserved. This book, or parts thereof, may not be reproduced in any form or by any means, electronic or mechanical, including photocopying, recording or any information storage and retrieval system now known or to be invented, without written permission from the Publisher.

For photocopying of material in this volume, please pay a copying fee through the Copyright Clearance Center, Inc., 222 Rosewood Drive, Danvers, MA 01923, USA. In this case permission to photocopy is not required from the publisher. 
It is an essential characteristic of experimentation that it is carried out with limited resources, and an essential part of the subject of experimental design to ascertain how these should best be applied.

- Sir Ronald A. Fisher

Our observations of Nature must be diligent, and our experiments exact.

- Denis Diderot 
This page intentionally left blank 


\section{CONTENTS}

\section{Chapter 1}

Introduction: How Physics Defines the LHC Environment

and Detectors

D. Green

\section{Chapter 2}

The CMS Pixel Detector

W. Erdmann

Chapter 3

The Hybrid Tracking System of ATLAS

Leonardo Rossi

\section{Chapter 4}

The All-Silicon Strip CMS Tracker: Microtechnology at the Macroscale

M. Mannelli

\section{Chapter 5}

The ATLAS Electromagnetic Calorimeters: Features

and Performance

Luciano Mandelli

Chapter 6

The CMS Electromagnetic Calorimeter: Crystals and

APD Productions

P. Bloch

Chapter 7

ATLAS Electronics: An Overview

Philippe Farthouat 


\section{Chapter 8}

Innovations in the CMS Tracker Electronics

G. Hall

\section{Chapter 9}

TileCal: The Hadronic Section of the Central ATLAS Calorimeter

K. Anderson, T. Del Prete, E. Fullana, J. Huston,

C. Roda and R. Stanek

Chapter 10

Innovations for the CMS HCAL

J. Freeman

Chapter 11

ATLAS Superconducting Toroids — The Largest Ever Built

Herman H. J. ten Kate

Chapter 12

Constructing a 4-Tesla Large Thin Solenoid at

the Limit of What Can Be Safely Operated

A. Hervé

Chapter 13

The ATLAS Muon Spectrometer

Giora Mikenberg

Chapter 14

The CMS Muon Detector: From the First Thoughts

to the Final Design

Fabrizio Gasparini

\section{Chapter 15}

The Why and How of the ATLAS Data Acquisition System

Livio Mapelli and Giuseppe Mornacchi

Chapter 16

Removing The Haystack — The CMS Trigger

and Data Acquisition Systems

Vivian O'Dell 